\title{
LII. Analyses of the ashes of rough brown sugar and molasses
}

\section{Thomas Richardson}

To cite this article: Thomas Richardson (1847) LII. Analyses of the ashes of rough brown sugar and molasses, Philosophical Magazine Series 3, 31:209, 336-338, DOI: 10.1080/14786444708645862

To link to this article: http://dx.doi.org/10.1080/14786444708645862

册 Published online: 30 Apr 2009.

Submit your article to this journal $₫$

Џ Article views: 2

Q View related articles $₫$ 
LII. Analyses of the Ashes of Rough Brown Sugar and Molasses. By Thomas Richardon*.

DRING some inquiries which I had occasion to make in the manufacture of an artificial manure for the sugarcane, it was necessary to know the composition of the ash of coarse brown sugar and molasses as imported into this country. The results may be interesting to some of the readers of your Journal.

\section{Rough Brown Sugar.}

206.48 grs. in its ordinary state left 2.74 grs. ash $=1.93$ per cent. 143.05 grs. of ash furnished $18.16 \mathrm{grs}$. silica, and 4.75 grs. carbonic acid.

28.61 grs. of ash furnished $8 \cdot 43$ grs. $\mathrm{SO}_{3} \mathrm{BaO}=2 \cdot 89$ grs. sulphuric acid.

$28.61 \mathrm{grs}$. of ash furnished $0.19 \mathrm{gr}$. oxide of copper.

28.61 grs. of ash furnished $1.95 \mathrm{gr}$. peroxide of iron. lime.

28.61 grs. of ash furnished 7.00 grs. $\mathrm{CO}_{2} \mathrm{CaO}=3.92$ grs.

$28.61 \mathrm{grs}$. of ash furnished $7.81 \mathrm{grs} . \mathrm{PO}_{5} 2 \mathrm{MgO}=2 \cdot 86 \mathrm{grs}$. magnesia.

16.12 grs. of ash furnished $7.36 \mathrm{grs} . \mathrm{Cl}_{2} \mathrm{Ag}=1.96 \mathrm{gr}$. chlorine.

$28.61 \mathrm{grs}$. of ash furnished $28.61 \mathrm{grs}$. chlorides of alkalies, and this yielded 33.88 grs. of the double chloride of platinum and potassium $=10.34$ grs. chloride of potassium $=6.53 \mathrm{grs}$. potash, leaving $4 \cdot 16$ grs. chloride of sodium $=2 \cdot 20$ grs. soda. The ash also contained a trace of oxide of manganese.

The result of the analysis is therefore-

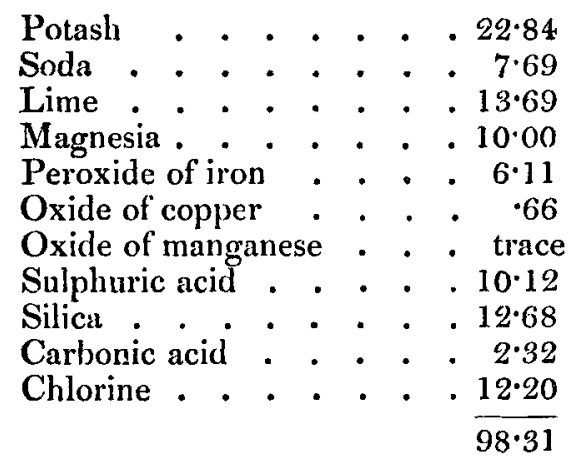

* Communicated by the Author. 
Omitting the carbonic acid and combining the chlorine with the sodium and potassium, we obtain the following composition in 100 parts :-

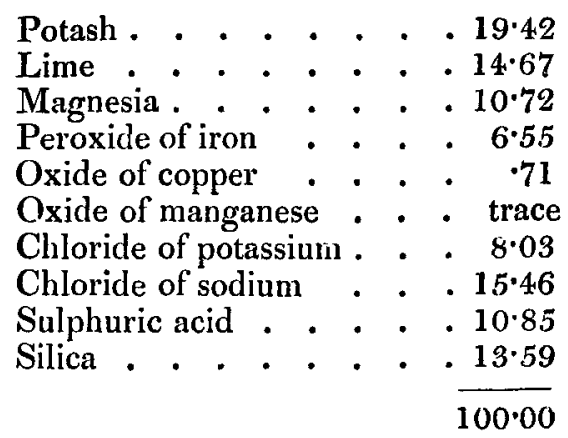

\section{Molasses.}

Great difficulty was experienced in incinerating the bulky charcoal mass left by boiling down the molasses. Part of the oxide of iron and sulphuric acid were decomposed; and this accounts for the excess in the analysis, as these substances were obviously in part twice estimated. $477.77 \mathrm{grs}$. left 17.21 grs. ash $=3.60$ per cent.

$64.27 \mathrm{grs}$. of ash furnished $6.46 \mathrm{grs}$. carbonic acid.

$64.27 \mathrm{grs}$. of ash furnished 8.65 grs. charcoal, containing $.55 \mathrm{gr}$. peroxide of iron and $.26 \mathrm{gr}$. lime.

$64.27 \mathrm{grs}$. of ash furnished $1.02 \mathrm{gr}$. silica.

$21 \cdot 423 \mathrm{grs}$. of ash furnished $\cdot 28 \mathrm{gr}$. peroxide of iron. lime.

$21 \cdot 423$ grs. of ash furnished $3 \cdot 83$ grs. $\mathrm{CO}_{2} \mathrm{CaO}=2 \cdot 14 \mathrm{grs}$.

$21 \cdot 423 \mathrm{grs}$. of ash furnished 5.34 grs. $\mathrm{PO}_{5} 2 \mathrm{MgO}=1.95 \mathrm{gr}$. magnesia.

$21 \cdot 423$ grs. of ash furnished chlorides of alkalies $14.91 \mathrm{grs}$, and this gave chlorides of platinum and potassium 32.88 grs. $=\mathrm{Cl}_{2} \mathrm{~K}$ 10.34 grs., leaving $\mathrm{Cl}_{2} \mathrm{Na} 4.57$ grs., = potash 6.53 and soda $2 \cdot 4.2 \mathrm{grs}$.

12.62 grs. of ash furnished 2.38 grs. $\mathrm{SO}_{3} \mathrm{BaO}=\cdot 81 \mathrm{gr}$. sulphuric acid.

18.405 grs. of ash furnished $9.92 \mathrm{grs} . \mathrm{Cl}_{2} \mathrm{Ag}=2.453 \mathrm{grs}$. chlorine.

The ash also contained traces of oxides of copper and manganese.

Collecting these results we obtain the following composition: Phil. Mag. S. 3. Vol. 31. No. 209. Nov. 1847. 


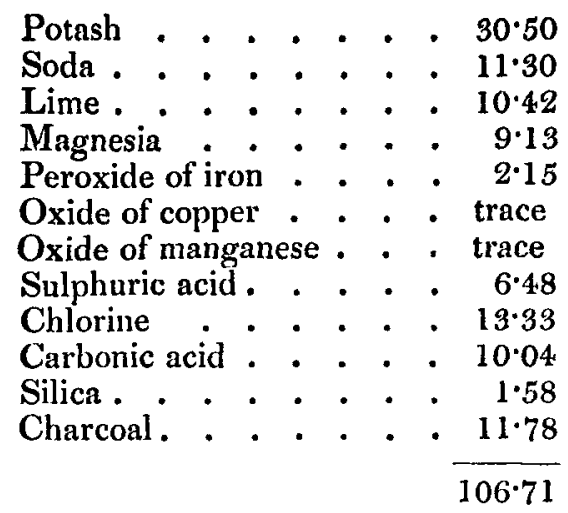

Omitting the charcoal and carbonic acid, and combining the chlorine as before, we have as follows:-

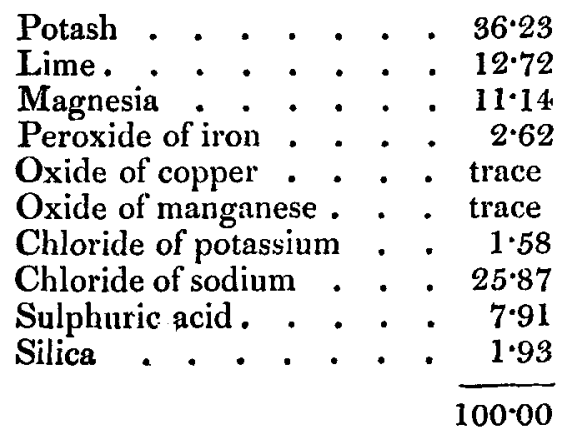

The molasses and sugar came from the same manufactory, and were made from the same sugar-cane.

LIII. Letter from Professor Loomis of the New York University to Lieut.-Colonel Sabine, Foreign Secretary of the Royal Society, on the determination of differences of Longitude made in the United Slates by means of the Electric Telegraph, and on projected observations for investigating the Lates of the great North American Storms.

Dear Sir,

New York University, Aug. 2, 1847.

THAVE been for some time engaged upon a work in which 1 you may perhaps feel some interest, -it is the exact determination of the difference of longitude between New York, Philadelphia and Washington, by means of the magnetic 